\title{
REFLECTION
}

\section{The Immortality of Ms Jones}

Timotby Gallagher, BA, BFA

New York University School of Medicine New York, New York
Conflicts of interest: author reports none.

\section{CORRESPONDING AUTHOR}

Timothy Gallagher, BA, BFA New York University School of Medicine 189 Avenue C, Apt 2B

New York, NY 10009

thg204@nyumc.org

\begin{abstract}
When I began my medical student clinical rotations, I quickly became overwhelmed by feelings of inadequacy. While the doctors around me conjured appropriate diagnoses and treatment approaches, I fumbled with the only tools I possessed: my time and a smile. It was only when I met the patient Ms Jones that I came to understand the potential impact of these simple tools. My encouragement became part of her recovery process. She gave me the confidence to construct this ability of comforting patients into a small platform of confidence from which I could safely venture to educate patients or suggest treatments to residents. It could be something that I could reliably fall back on in times of doubt and something I could pass along to other people I met.
\end{abstract}

Ann Fam Med 2014;373-374. doi: 10.1370/afm.1645.

$\mathrm{T}$ They tell you it's going to be hard. They tell you about sleepless nights on call at the hospital, about missing friends and birthdays and barbecues. I heard it all and still retained my excitement for medical school. Surely long nights of research and weekends full of memorization would equip me to solve problems and save lives.

They don't tell you about vulnerability, about the crushing feeling of inadequacy. I never foresaw myself paralyzed on the hospital wards, overwhelmed by a quagmire of statistics and symptoms that were churning in my head and yet refusing to coalesce into anything resembling a diagnosis for my patient. All the while, doctors and nurses purposefully glided around me.

Ms Jones came onto our medical service to be evaluated for wide complex tachycardia, her heart's ventricles would start racing without provocation. Other than giving birth to 13 children, she had never been hospitalized. One day, she was playing Monopoly with her son, and she felt palpitations in her chest. She began to worry, and then in the hospital, when she was hooked up to intravenous lines and monitors, she became scared.

On the first day, I couldn't offer much more than a smile. I held her hand and explained what I knew about the basic mechanisms of cardiodynamics. Mostly, I listened to her concerns. She had never taken medication for anything more than a transient infection, but now cardiologists were talking about threading wires through the veins from her hip to her heart, possibly implanting mechanical devices into her chest, and almost certainly putting her on medication for the rest of her life. Ms Jones looked up from her bed with a face accustomed to the undisputed authority of a southern Baptist mother, with warm brown eyes surrounded by intricate etchings from years of laughter. Eyes that now welled with a glossy fear. I went home at night and studied her condition. I read about ventricular tachycardia and supraventricular tachycardia with aberrancy, about ablation and pacemakers. As a fledgling physician-in-training at her bedside, as I fumbled through explanations of cardiac pathophysiology, I slowly realized she had much more to offer me.

She worked as a store clerk, a manager, a singer songwriter, a construction worker, a window display dresser, a home health aide, a patient advo- 
cate, a social worker, a paralegal. I asked her why she would leave one job to move on to another, and she replied that you never leave anything behind:

Now I'm working on opening a home for transgendered people in the city. Everyone tears them down, and they need help. When I design the building, I have to imagine how it will invite them in from the streets, like when I was a window dresser. I have to make sure they have a safe environment up to spec with the building codes I learned in construction. I need to make sure my social workers know about addiction and medication and the shelter system. I'm taking along everything I've learned. I'm not leaving anything behind.

Ms Jones was transferred from our general medicine floor to the cardiac unit, but I continued to visit her each evening before I left the hospital. She said my smile lifted her spirits. I hoped it would settle her nerves when I accompanied her to the catheterization lab and waved through the observation window.

Was I comforting her, or was she comforting me? No matter how my day went, how inept I felt next to the residents and attending physicians, I knew at least this one patient would be thankful to see me at the end of the day. I came to realize my smile and reassurance could tether Ms Jones to an optimistic prospect of recovery, and this alone was something worth investing in. I constructed this ability of comforting patients into a small platform of confidence from which I could safely venture to educate patients or suggest treatments to residents. Like Ms Jones's paralegal work, it would be something I could reliably fall back on.

"You need to give back what God gave you," Ms Jones told me. "I try to expand what I've learned and give it out to others." Her smile felt like a hug. "Then you have to keep your faith and let them pick it up if they can."

My friend Katie once told me she believed in reincarnation. I stared at her blankly. She continued, "I think that a little piece of me lives on in the people I've talked to, and helped, and shared things with. I've changed who they are, and how they treat others. Like dominos, my spirit will carry itself along."

So, I bundle up the lessons I learned from the lovely Ms Jones and embellish them with a smile for now. I will pass these lessons along to my friends and patients. I will reassure them that nothing is lost, and I will try to show them how every past experience is a future tool. I will encourage them to smile. And I will watch fondly as the spirit of Ms Jones dominoes along.

To read or post commentaries in response to this article, see it online at http://www.annfammed.org/content/12/4/373.

Key words: humanities; delivery of health care; clinical medicine; education, medical, undergraduate

Submitted August 22, 2013; October 30, 2013; December 10, 2013.

\section{Read the blogs on AAFP News. Relevant, trusted, and authentic.}

FRESH PERSPECTIVES NEW DOCS IN PRACTICE

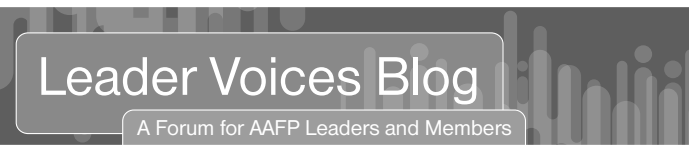

Fresh Perspectives Blog

Share the insights and experiences of new-to-practice family physicians.

aafp.org/freshperspectives

\section{AAFP Leaders Blog}

Take part in a two-way discussion on issues important to family medicine.

aafp.org/leadervoices 